\title{
ANALISIS KEMAMPUAN SISWA DALAM MENYELESAIKAN MASALAH BERDASARKAN TEORI APOS DITINJAU DARI TIPE KEPRIBADIAN DAVID KEIRSEY
}

\author{
${ }^{1}$ Robisha Zarifa Riba'ah, ${ }^{2}$ Mohammad Kholil \\ ${ }^{1}$ IAIN Jember, Jl. Mataram No. 1 Mangli, (0331) 487550 \\ ${ }^{2}$ IAIN Jember, Jl. Mataram No. 1 Mangli, (0331) 487550 \\ robisha.zarifa@gmail.com
}

\begin{abstract}
Abstrak
Tujuan penelitian ini adalah: (1) untuk mendeskripsikan kemampuan menyelesaikan masalah berdasarkan teori APOS ditinjau dari kepribadian tipe guardian, (2) untuk mendeskripsikan kemampuan menyelesaikan masalah berdasarkan teori APOS ditinjau dari kepribadian tipe artisan, (3) untuk mendeskripsikan kemampuan menyelesaikan masalah berdasarkan teori APOS ditinjau dari kepribadian tipe idealis. Pendekatan dalam penelitian ini adalah kualitatif dengan jenis penelitian studi kasus. Adapun teknik dalam pengumpulan data dengan tes, wawancara, dan dokumentasi. Subjek dalam penelitian ini adalah delapan siswa kelas XA yang terdiri dari tiga siswa bertipe guardian, tiga siswa bertipe artisan, dan dua siswa bertipe idealis. Hasil penelitian menunjukkan bahwa (1) siswa dengan tipe kepribadian guardian berada pada semua tahapan APOS yaitu aksi, proses, objek, dan skema. Akan tetapi untuk soal yang sulit siswa bertipe guardian hanya berada pada dua tahapan yang berbeda-beda dari setiap siswa. (2) siswa dengan tipe kepribadian artisan untuk soal yang mudah berada pada semua tahapan APOS yaitu aksi, proses, objek, dan skema. Akan tetapi untuk soal yang sulit siswa bertipe artisan hanya berada pada tahap aksi. (3) siswa dengan tipe kepribadian Idealis untuk soal yang mudah hanya berada pada tiga tahapan APOS saja dan berbeda-beda. Akan tetapi untuk soal yang sulit siswa bertipe idealis hanya berada pada tahap aksi.
\end{abstract}

Kata Kunci: Teori APOS, SPLTV, Tipe kepribadian David Keirsey.

\begin{abstract}
The purpose of this research is to (1) to describe the ability to solve problem based on APOS theory in terms of personality Guardian types (2) to describe the ability to solve problem based on APOS theory in terms of personality Artisan types (3) to describe the ability to solve problem based on APOS theory in terms of personality Idealis types. The approach in this research is qualitative with the type of case study research. Data collection techniques by tes, interview, and documentation. The subjects in this studywere eigt XA class students consisting of three guardian type, three artisan type,and two idealis type. The result of reasearch showed that (1) students with guardian personality types are at all stages of APOS namely action, process, object, and scheme. However, for difficult questions guardian type students are only at two different stages of each student. (2) students with artisan personality types for easy questions are at all stages of APOS namely action, process, object, and scheme. However, for difficult problems, the artisan type students are only at the action stage.(3) students with idealistic personality types for easy questions are only in three stages of APOS and are different. However, for difficult problems idealistic type students are only at the action stage.
\end{abstract}

Keywords: The ability to solve problems, APOS Theory, SPLTV, David Keirsey's personality type.

\section{PENDAHULUAN}

UU RI No. 20 Tahun 2003 menjabarkan fungsi pendidikan nasional yaitu untuk mengembangkan dan membentuk watak serta peradaban bangsa yang bermartabat dalam rangka mencerdaskan kehidupan bangsa. Hal ini dapat tercapai melalui pengembangan 
segenap potensi yang dimiliki siswa melalui pendidikan. Siswa dilatih agar memiliki pola pikir analitis dan bukannya pola pikir mekanistis serta dapat bekerja sama dalam menyelesaikan masalah (Prastiwi \& Nurita, 2018)

Kemampuan menyelesaikan masalah sangat dibutuhkan oleh setiap orang. Menurut Martinis pemecahan masalah adalah strategi yang merangsang berpikir dan menggunakan wawasan tanpa melihat kualitas pendapat yang disampaikan siswa (Yamin, 2007). Kemampuan pemecahan masalah merupakan hal yang sangat penting dalam pembelajaran. Terutama dalam pembelajaran matematika melalui pemecahan masalah maka siswa akan mempunyai kemampuan yang lebih dari kemampuan berpikir, dan dapat membuat penyelesian-penyelesaian untuk masalah selanjutnya. Dalam matematika tetunya akan dapat ditemukan masalah masalah yang harus dipecahkan, salah satu materi wajib yang harus diperoleh siswa kelas $\mathrm{X}$ dan sering dijumpai dalam bentuk masalah atau soal cerita adalah Sistem Persamaan Linear Tiga Variabel (SPLTV).

Kemampuan pemacahan masalah matematika pada siswa tidak dapat dibiarkan begitu saja, siswa harus dapat mengembangkan kemampuan pemecahan masalah tersebut. Oleh karena itu, dibutuhkan suatu analisis terhadap kemampuan pemecahan masalah yang dilakukan siswa. Untuk mengetahui kemampuan pemecahan masalah siswa dibutuhkan suatu analisis. Menurut Peter (Salim \& Salim, 2002) analisis adalah penyelidikan terhadap suatu peristiwa untuk mendapatkan fakta yang tepat (asal usul, sebab, penyebab sebenarnya, dan sebagainya). Salah satu teori yang dapat digunakan sebagai analisis untuk mengetahui kemampuan pemecahan masalah matematika siswa adalah teori APOS. Teori APOS merupakan teori yang mempelajari bagaimana individu belajar konsep matematika. Teori ini mengemukakan bahwa dalam membangun sebuah konsep matematika, individu melalui tahap-tahap aksi, proses, objek, dan skema. Teori APOS telah digunakan dalam beberapa penelitian mengenai pemahaman mahasiswa dan siswa tentang berbagai topik matematika. Menurut Nerly Teori APOS dapat digunakan secara langsung dalam membandingkan keberhasilan atau kegagalan individu yang berkaitan dengan konstruksi mental yang telah terbentuk untuk suatu konsep matematika.

Ketika melakukan analisis kemampuan pemecahan masalah matematika maka akan ditemui berbagai macam karakteristik siswa. Setiap orang mempunyai kepribadian yang berbeda-beda, sehingga proses berpikir setiap individu juga tergantung dari kepribadian masing-masing. Oleh karena itu akan sangat membantu jika guru mengetahui tipe kepribadian setiap siswa. Salah satu tipe kepribadian menurut David Keirsey terbagi menjadi 4 yaitu Guardian, Artisan, Rasional, dan Idealis (S, 2009). Akan tetapi pada penelitian ini 
untuk tipe kepribadian David keirsey peneliti hanya menggunakan 3 tipe kepribadian. Hal ini dikarenakan setelah dilakukan tes tipe kepibradian david keirsey di SMA Unggulan BPPT Darus Sholah seluruh siswa kelas XA hanya memiliki 3 tipe kepribadian yaitu guardian, artisan dan rasional. Kepribadian merupakan susunan unsur-unsur akal dan jiwa yang menentukan perbedaan tingkah laku atau tindakan dari tiap-tiap individu manusia. Alasan peneliti menggunakan tipe kepribadian david keirsey karena tipe kepribadian ini menjelaskan tentang karakteristik siswa dalam proses pembelajaran selain itu belom pernah ada yang melakukan penelitian tentang kemampuan menyelesaikan masalah berdasarkan teori APOS yang ditinjau dari tipe kepribadian david keirsey.

Berdasarkan observasi awal peneliti di SMA Unggulan BPPT Darussholah jember Sebagian besar siswa sudah mampu dalam menggali pemahaman konsep serta pengaplikasiannya dalam bentuk soal yang berkaitan dengan materi SPLTV. Dari uraian di atas, peneliti memiliki tujuan untuk mengetahui kemampuan menyelesaikan masalah siswa materi sistem persamaan linear tiga variabel berdasarkan teori APOS pada masing masing siswa dengan tipe kepribadian yang berbeda. Oleh karena itu, perlu dilakukan penelitian yang berjudul "Analisis Kemampuan Menyelesaikan Masalah Berdasarkan Teori APOS ditinjau dari Tipe Kepribadian David Keirsey.

\section{METODE PENELITIAN}

Pendekatan dalam penelitian ini adalah kualitatif dengan jenis penelitian studi kasus. Lokasi yang dipilih untuk dijadikan penelitian ini bertempat di SMA Unggulan BPPT Darus Sholah yang terletak di Jl. M. Yamin 25 Tegal Besar Kaliwates Kabupaten Jember. yang akan dipusatkan pada kelas XA yang dianggap dapat memenuhi informasi yang dibutuhkan karena pada kelas XA memiliki nilai dalam pembelajaran matematika yang cukup tinggi. Teknik pengumpulan data menggunakan tes, wawancara, dan dokumentasi. Subjek dalam penelitian ini adalah 8 siswa kelas XA dalam penelitian ini sample diambil secara purposive. Untuk menguji keabsahan data dalam penelitian ini menggunakan triangilasi teknik.

Proses pelaksanaan diawali dengan Obesarvasi di SMA Unggulan BPPT Darus Sholah Jember. Peneliti mengajukan surat peneletian dan disetujui oleh pihak SMA Unggulan BPPT Darus Sholah Jember. Kemudian selanjutnya untuk pelaksanaan observasi kelas, tes dan wawancara peneliti berdiskusi dengan guru matematika kelas XA. kemudian peneliti melakukan tes tipe kepribadian david keirsey pada seluruh siswa kelas XA, soal tes diambil dari buku david keirsey yang berjudul "Please Understand $M e$ " . Kemudian seluruh siswa 
diberikan lembar tes tipe kepribadian, dari hasil tes tersebut siswa dikelompokkan berdasarkan tipe kepribadian masing-masing, terdapat 4 tipe kepribadian david keirsey, Akan tetapi dalam penelitian ini hanya menggunakan 3 tipe kepribadian yaitu Guardian, Artisan, dan Idelais. Setelah seluruh siswa dikelompokkan berdasarkan tipe kepribadian masingmasing kemudian peneliti mengambil 3 siswa yaitu dari setiap tipe kepribadian diambil 1 untuk diberikan tes selanjutnya yaitu tes uraian soal SPLTV.

Tes terdiri 2 soal sistem persamaan linear tiga variabel. Soal tersebut memiliki tingkat kesulitan yang berbeda, soal nomer 1 merupakan sal yang mudah untuk dikerjakan, sedangkan soal nomer 2 merupakan soal yang sulit untuk dikerjakan. Dalam pelaksanaannya waktu yang diberikan adalah 40 menit. Berikut adalah sosal tes yang diberikan kepada siswa kelas XA SMA Unggulan BPPT Darus Sholah Jember.

a. Soal nomor 1

Zahra, Fitri dan Nia pergi bersama-sama ke toko sembako. Zahra membeli $3 \mathrm{~kg}$ jagung, $3 \mathrm{~kg}$ gula, dan $2 \mathrm{~kg}$ beras dengan Rp. 72.000,00. Fitri membeli $4 \mathrm{~kg}$ jagung, $2 \mathrm{~kg}$ gula, dan $2 \mathrm{~kg}$ beras dengan harga Rp. 66.000,00. Nia membeli $2 \mathrm{~kg}$ jagung, $4 \mathrm{~kg}$ gula, dan $3 \mathrm{~kg}$ beras dengan harga Rp. 80.000,00. Tentukan harga $1 \mathrm{~kg}$ jagung, $1 \mathrm{~kg}$ gula, dan $1 \mathrm{~kg}$ beras!

\section{b. Soal nomor 2}

Anton akan membuat mainan dengan tali rafia ia mempunyai tali rafia berwarna merah, kuning dan hijau. Jumlah panjang ketiga tali rafia tersebut $160 \mathrm{~cm}$. Panjang tali merah $10 \mathrm{~cm}$ lebihnya dari jumlah panjang tali kuning dan hijau. Panjang tali kuning sama dengan $14 \frac{1}{-4}$ dari jumlah panjang tali merah dan hiiau. Paniang tali merah adalah..... cm

Setelah dilakukan tes soal tersebut peneliti juga melakukan wawancaral dengan delapan siswa tersebutyang terdiri dari 3 siswa mewakili tipe kepribadian guardian, tiga siswa mewakili tipe kepribadian artisan, dan dua siswa mewakili tipe kepribadian Idealis. Untuk memudahkan untuk memahami dan menganalisa data ketika wawancara maka peneliti merekam hasil wawancara dengan alat perekam selain itu peneliti juga mendokumentasikan proses wawancara dengtan foto.

\section{HASIL DAN PEMBAHASAN}

Berdasarkan hasil tes tipe kepribadian ditemukan 16 siswa bertipe gauardian, 6 siswa bertipe Artisan, 2 siswa bertipe idealis dari 24 siswa kelas XA SMA Unggulan BPPT Darus Sholah Jember Jember. Berikut hasil dan pembahasan dari subjek yang dikodekan ANK, YNR dan LAN

1. Kemampuan menyelesaikan masalah siswa bertipe kepribadian Guardian 


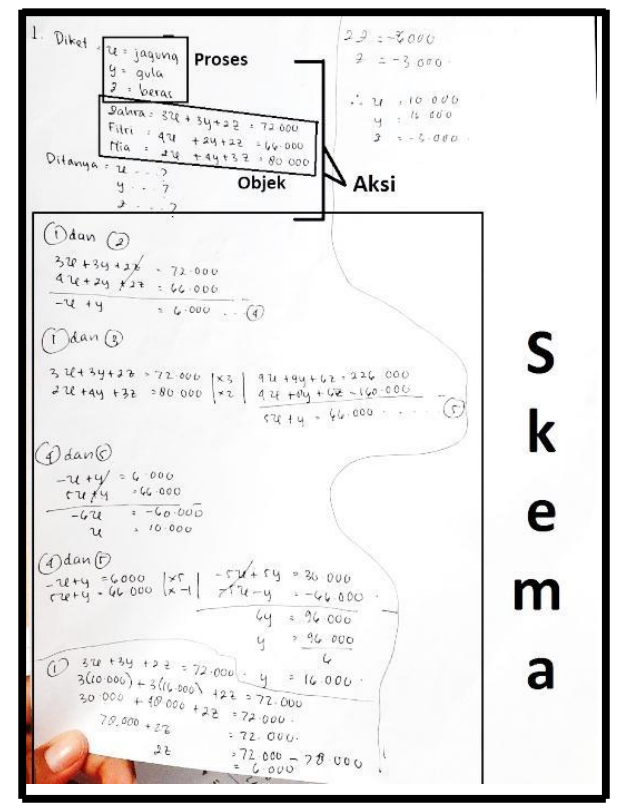

Gambar 1 Lembar jawaban soal 1 ANK

Berdasarkan hasil jawaban ANK tersebut pada tahap aksi ia menuliskan apa yang diketahui dan ditanyakan pada soal dengan cara langsung ia singkat dalam penulisannya. Begitupun juga ketika wawancara ia menjelaskan kembali. Pada tahap proses ia memisalkan jagung, gula dan beras menjadi variabel yaitu $\mathrm{x}, \mathrm{y}$, dan $\mathrm{z}$, akan tetapi ketika wawancara peneliti bertanya kepada ANK tentang yang dirubah menjadi $\mathrm{x}, \mathrm{y}$ dan $\mathrm{z}$ itu nama benda atau harga benda, ANK menjawab variabel itu adalah benda dan bukan harga benda.. Pada tahap objek ia mampu menerapkan apa yang ada pikirannya menjadi bentuk sistem persamaan linear tiga variabel, dan siswa membuat pemodelan matematika dari soal tersebut yaitu zahra $=3 x+3 y+2 z=72.000$, fitri $=4 x+2 y+2 z=66.000$, dan Nia $=$ $2 x+4 y+3 z=80.000$. Pada tahap skema ANK mampu menyelesaikan pemodelan matematika yang di buat sebelumnya dapat dilihat dari hasil tes dan wawancara cara, ia menggunakan metode eliminasi untuk menyelesaikan soal, siswa mampu menyelesaikan metode eleminasi dari soal tersebut dan ia menemukan jawabannya walaupun jawaban yang ia dapatkan kurang tepat.

2. Kemampuan menyelesaikan masalah siswa bertipe kepribadian Artisan 


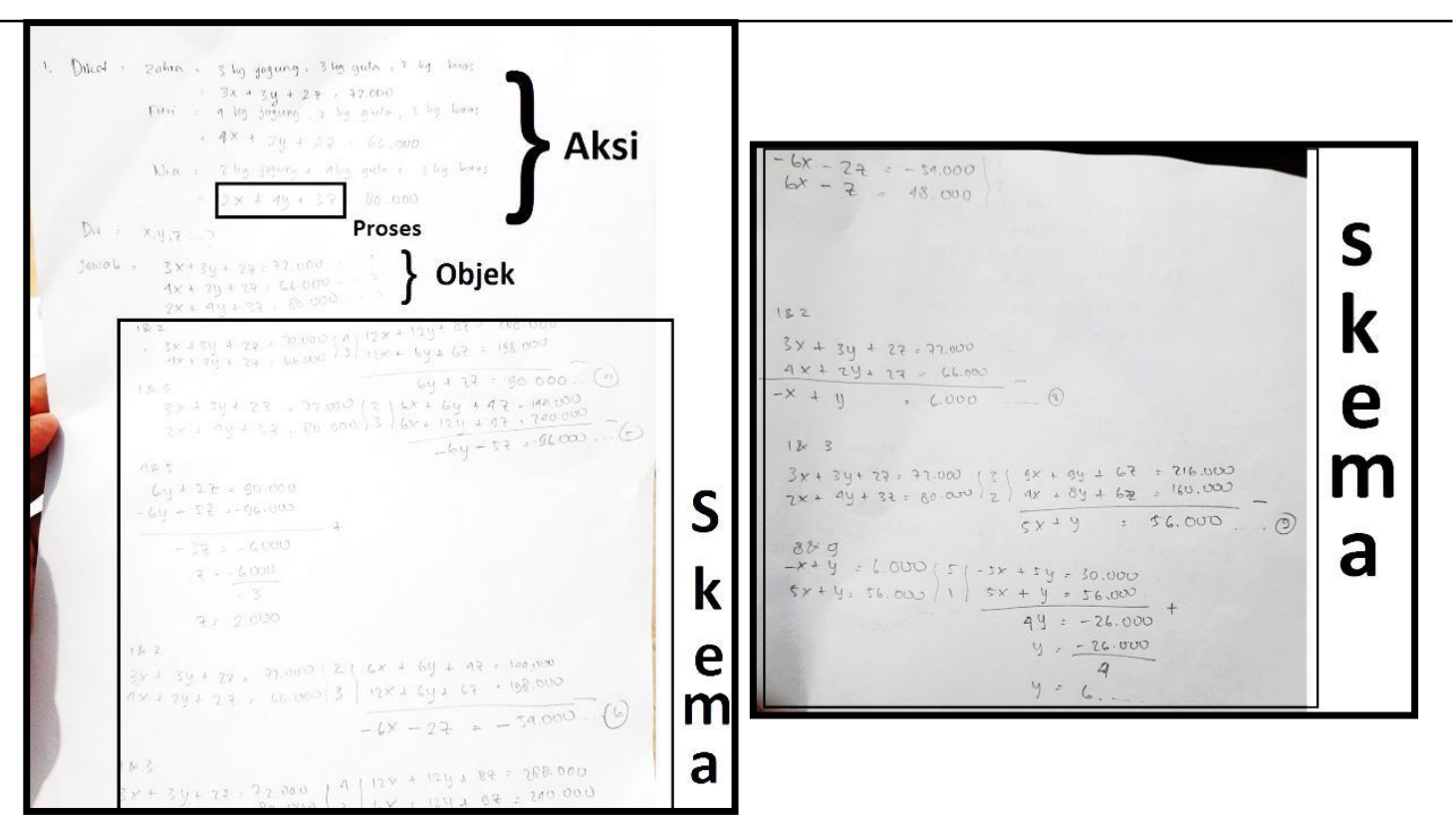

Gambar 2 Lembar jawaban soal 1 YNR

Dari hasil jawaban YNR diatas pada tahap aksi ia menuliskan yang ia ketahui dengan jelas dari masing-masing anak yang diketahui ia kelompokkan seperti zahra, fitri, dan Nia dan ia juga menuliskan yang ditanyakan pada soal dengan dipersingkat yaitu x, y, z. Pada tahap proses YNR memisalkan apa yang diketahu menjadi variabel akan tetapi ia tidak menuliskannya langsung pada tes dan berdasarkan hasil wawancara Ia menjelaskan bahwa ia mengubah jagung gula dan beras menjadi variabel yaitu $\mathrm{x}, \mathrm{y}$ dan $\mathrm{z}$ akan tetapi Iya tidak memahami bahwa yang di misalkan itu adalah harga jagung, gula dan beras. Pada tahap objek ia menjadikan $3 x+3 y+2 z=72.000$ sebagai persamaan 1. $4 x+2 y+2 z=66.000$ sebagai persamaan 2. Dan $2 x+4 y+3 z=80.000$ sebagai persamaan 3. Pada tahap skema YNR mampu menyelesaikan persamaan linear tiga variabel dari pemodelan yang ia buat, YNR dalam menyelesaikannya menggunakan metode eliminasi. YNR mampu mengerjakan soal dan memahaminya serta memecahkan jawaban berdasarkan urutan teori APOS walaupun jawaban yang ia temukan kurang tepat.

3. Kemampuan menyelesaikan masalah siswa bertipe kepribadian Idealis. 


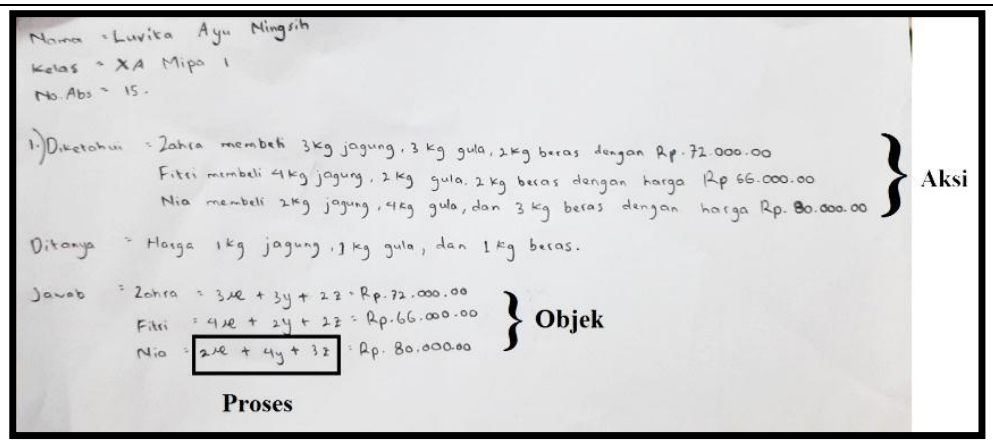

Gambar 2 Lembar jawaban soal 1 LAN

Dari hasil Jawaban LAN dapat dilihat pada tahap aksi ia menuliskan dengan jelas semua informassi yang ada pada soal ia juga menuliskan yang ditanyakan pada soal. Pda tahap proses LAN memisalkan yang ia ketahui menjadi variabel. Walaupun ia tidak menuliskannya secara langsung. Ia memisalkan dengan $x$, y dan z. Pada tahap objek ia membuat model matematika pada soal tersebut yiatu untuk zahra $=3 x+3 y+2 z=72.000$. untuk Fitri $4 x+2 y+2 z=66.000$. dan Nia $=2 x+4 y+3 z=80.000$.

Siswa yang bertipe kepribadian guardian yaitu dengan ciri ciri lebih suka mengikuti prosedur yang rutin dengan instruksi yang detail, atau dengan kata lain tipe guardian menyukai kelas dengan model tradisional dengan prosedur yang teratur. Dalam mengerjakan soal adalah siswa mampu memahami materi sistem persamaan linear tiga variabel yang ada padaa soal nomer 1 dan 2 . Siswa guardian juga mampu menyelesaikan soal nomer 1 dan 2 tersebut walaupun masih ada yang kurang tepat. Tahapan menyelesaikan masalah tersebut berdasarkan teori APOS siswa yang memiliki tipe kepribadian guardian berada pada semua tahapan APOS yaitu aksi, proses, objek, dan skema. Akan tetapi untuk soal yang sulit siswa bertipe kepribadian hanya berada pada 2 tahapan saja.

Siswa yang bertipe kepribadian artisan yaitu dengan karakteristik menyukai bentuk kelas yang banyak diskusi dan presentasi karena tipe ini cenderung ingin menunjukan kemampuannya, serta menyukai perubahan dan tidak suka terhadap kestabilan. Dalam mengerjakan soal siswa artisan mampu memahami materi sistem persamaan linear tiga variabel yang ada pada soal nomer 1 dan 2. Siswa artisan hanya mampu menyelesaikan masalah pada soal yang tergolong mudah dan tidak dapat menyelesaikan soal yang sulit. Tahapan menyelesaikan masalah tersebut berdasarkan teori APOS siswa yang memiliki tipe kepribadian artisan untuk soal yang mudah berada pada semua tahapan APOS yaitu aksi, 
proses, objek, dan skema. Akan tetapi untuk soal yang sulit siswa bertipe kepribadian hanya berada pada tahap aksi.

Siswa yang bertipe kepribadian idealis yaitu dengan karakteristik lebih menyukai menyelesaikan tugas secara diskusi kelompok, menyukai membaca dan menulis sehingga lebih cocok jika diberi tes berbentuk uraian atau soal cerita. Dalam mengerjakan soal siswa idealis mampu memahami materi sistem persamaan linear tiga variabel yang ada pada soal nomer 1 dan 2. Siswa Idealis hanya mampu menyelesaikan masalah pada soal yang tergolong mudah dan tidak dapat menyelesaikan soal yang sulit. Tahapan menyelesaikan masalah tersebut berdasarkan teori APOS siswa yang memiliki tipe kepribadian Idealis untuk soal yang mudah hanya berada pada tiga tahapan APOS saja. Akan tetapi untuk soal yang sulit siswa bertipe kepribadian idealis hanya berada pada tahap aksi.

\section{SIMPULAN DAN SARAN}

Berdasarkan hasil dan pembahasan dapat disimpulkan bahwa kemampuan siswa dalam menyelesaikan masalah berdasarkan teori APOS ditinjau dari tipe kepribadian david keirsey pada soal yang mudah siswa bertipe guardian dan artisan mampu memenuhi semua indikator tahapan APOS yaitu aksi, proses objek dan skema walaupun langkah-langkah yang digunakan dalam menyelesaikan masalah berbeda-beda. Sedangkan untuk siswa bertipe idealis hanya mampu memenuhi indikator 3 tahapan saja yaitu untuk subjek LAN berada pada tahapan aksi, proses, dan objek ia tidak mampu memenuhi indikator tahapan skema. Adapun saran yang ingin peneliti sampaikan yaitu Untuk guru, setiap siswa memiliki karakteristik dan tipe kepribadian yang berbeda-beda dalam menyelesaikan masalah matematika. Oleh karena itu, seorang guru sebaiknya memperhatikan kemampuan siswa dalam setiap proses pembelajaran, sehingga guru dapat mendesain kegiatan pembelajaran agar tujuan pembelajaran tercapai dengan efektif dan efesien.

\section{DAFTAR PUSTAKA}

\section{Books:}

Prastiwi, M. D., \& Nurita, T. (2018). Kemampuan pemecahan masalah pada siswa kelas VII SMP. Pensa: Jurnal Pendidikan Sains, 6(02).

S, M. J. D. (2009). Karakteristik Proses Berfikir Siswa Dalam Mempelajari Matematika Berbasis Tipe Kepribadian. Prosiding Seminar Nasional Penelitian.

Salim, P., \& Salim, Y. (2002). Kamus Bahasa Indonesia Kontemporer (Jakarta. Modern English Press. 
Yamin, M. (2007). Desain pembelajaran berbasis tingkat satuan pendidikan. Jakarta: Gaung Persada Press. 